\title{
EL RUNA YNDIO NIISCAP. TRADICIONES MÍTICO-HISTÓRICAS ANDINAS REGISTRADAS EN TEXTOS ESCRITOS PARA LA EXTIRPACIÓN DE IDOLATRÍAS Y LA EVANGELIZACIÓN: UN MODO PARADÓJICO DE PERSISTENCIA DE LA RELIGIÓN INDÍGENA. HUAROCHIRÍ, ¿1598-1608?*
}

\author{
THE YNDIO NISCAP RUNE. ANDEAN MYTHICAL-HISTORICAL TRADITIONS \\ IN WRITTEN TEXTS FOR THE EXTIRPATION OF IDOLATRIES AND \\ EVANGELIZATION: A PARADOXICAL MEAN OF INDIGENOUS RELIGIOUS \\ PERSISTENCE. HUAROCHIRÍ, ¿1598-1608?
}

\author{
Alejandro Herrera Villagra**
}

\begin{abstract}
La provincia de Huarochirí fue el lugar de origen de la extirpación de idolatrías en la primera década del siglo XVII. Allí el vicario Francisco de Ávila junto a un grupo de indígenas cristianos llevó adelante una investigación jurídico-eclesial aplicada a comunidades Yungas sospechosas de persistir secretamente en la práctica de creencias contrarias al dogma. Esta investigación incluyó visitas en terreno, interrogatorios, confiscación de objetos rituales y la construcción de textos en quechua. La investigación estuvo destinada a identificar las "fábulas" y "supersticiones" de la "idolatría" y su fin último fue crear información utilizable para la destrucción de sus aspectos ideológicos y materiales e, invariablemente, la evangelización forzada. En este ensayo desarrollamos un análisis mitográfico acerca de deidades de la Sierra Central que nos permite abordar nuestra hipótesis general respecto de la construcción de una memoria andina colonial basada en la práctica de la escritura indígena.

Palabras claves: Yungas, escritura y memoria indígena, Cuniraya Huiracocha, Pariacaca, evangelización y extirpación de idolatrías, investigación eclesial, traducción quechua-castellano.
\end{abstract}

The province of Huarochiri was the place of origin of the removal of idolatries in the first decade of the seventeenth century. There, the vicar Francisco de Avila along with a group of indigenous christians carried forward a legal-ecclesial research applied to Yungas communities suspected of secretly persisting in the practice of beliefs contrary to the dogma. This research included field visits, interrogations, confiscation of ritual objects and the construction of texts in quechua language. The research was designed to identify the "fables" and "superstition" of the "Idolatry" and its ultimate purpose was to create usable information for the destruction of their ideological and material aspects and, invariably, the forced evangelization. In this essay we develop a myth graphic analysis on deities of the Central Sierra that allows us to address our general hypothesis about the construction of a colonial andean memory based on the practice of the indigenous writing.

Key words: Yungas, indigenous writing and memory, Cuniraya Huiracocha, Pariacaca, evangelization and removal of idolatries, ecclesial research, quechua-spanish translation.

\section{Introducción}

A fines del siglo XVI en el antiguo territorio de Yauyos diferentes comunidades étnicas todavía practicaban sus antiguas creencias y tradiciones vinculadas a los ancestros y la naturaleza. Esas comunidades poseían evidentemente largas trayectorias en cuanto a sus orígenes y a sus desarrollos históricos y culturales. Fueron posiblemente herederas de antiguas tradiciones que se desarrollaron desde el Horizonte Intermedio Temprano. Sin embargo, su desarrollo social se mantuvo en el tradicional sistema de clanes de linajes confederados que a partir de pequeñas aldeas serranas controlaron territorios que consideraron su hogar natural por largos siglos. En el Horizonte Tardío (siglos XV-XVI), estas

\footnotetext{
* Resultado proyecto FONDECYT No 1130431.

** Universidad Nacional de San Antonio Abad del Cuzco (UNSAAC), Cuzco, Perú. Correo Electrónico: Alehv772@ hotmail.com
} 
comunidades étnicas de altura fueron intervenidas por los Intip Churin, pero sin perder su sistema de ideas religiosas según un especial tipo de alianza. A cambio, se vieron constreñidas por espacio de 100 años a la aceptación del sistema de jerarquía de los Incas, la ideología solar y sus implicancias sociales y económicas, especialmente aquellas relacionadas con la mita. Al caer el Tawantinsuyu (1533-34/1536-37), los Yungas de la sierra Central retornaron por un breve tiempo a sus tradiciones, cortadas sus relaciones con la llaqta huaca. Sus creencias y costumbres continuaron reproduciéndose hacia 1550-60, ya que por entonces comenzaron a ser fundados por españoles los primeros pueblos de indios de acuerdo con el esquema de las encomiendas, y empezó a fluir el proceso colonizador hacia la esfera mental, física y cultural denominada República de Indios.

Por entonces la vida de los Yungas todavía giraba en torno a sus viejos sistemas religiosos y culturales: el cultivo, crianza de animales, el tejido y la cerámica, actividades comunitarias y parentales (ayllus), el culto a los antepasados (mallquis) y a las deidades tutelares (apus, huacas), las fiestas y ceremonias, los mitos y los ritos naturales y sobrenaturales, los intercambios interétnicos, la lengua quechua local. Pero la vida colonial avanzaba inexorablemente con la pujanza característica de los españoles del período. Así pudo fundarse Santa María de Jesús de Huarochirí, capital del corregimiento de Yauyos, en 1565. Para la época del gobierno del virrey Francisco de Toledo (1569-1581) se lograron establecer oficialmente los pueblos de indios, entre ellos: San Pedro de Huancayre, San Lorenzo de Quinti, San Damián de Checa, Santa Ana de Chaucarima, San José de Chorrillos y San Francisco de Sisicaya. Fueron sacerdotes jesuitas quienes estuvieron allí desde un principio: Diego Bracamonte, Blas Valera y Alonso de Barzana, entre otros (Urbano ed. 1999: 12). En lo que sigue realizamos una reflexión antropológica acerca de los mitos y ritos de grupos étnicos andinos que tuvieron una trayectoria distinta a la Inca y una especial experiencia en el campo de la escritura andina. Para abordar este contexto vamos a estudiar el Runa Yndio Niscap o Manuscrito Quechua de Huarochirí, recurriendo a las versiones más importantes: la de José María Arguedas ([i1598?] 1966, 2012) y la de Gerald Taylor ([¿1608?] 1987, 1999), siguiendo un esquema mitográfico (Kirk 2006; Lévi-Strauss 2013).

\section{“Idolatrías", persecución y escritura}

Desde mediados del siglo XVI la evangelización avanzó hasta los lugares más recónditos de los Andes. Allí donde hubo pueblos indígenas llegó la religión única para imponer un nuevo sistema de vida. Los primeros concilios limenses, con especial énfasis el segundo y tercer concilio (1567 y 1582, respectivamente), ordenaron la conversión al cristianismo de los andinos innovando técnicas y métodos de conversión, de acuerdo con las experiencias político-religiosas emanadas en Europa desde el Concilio de Trento (1545-1563) ${ }^{1}$. En particular, gracias al uso del quechua misional, al sistema de escritura alfabética y la cultura del libro el proceso evangelizador dejó toda una gran herencia de información documental. Para utilizar historiográficamente estos registros debemos someterlos a un riguroso proceso heurístico, pues estas informaciones de doble carácter fueron notablemente manipuladas. En este sentido, el caso de los Yungas es interesantísimo para la etnohistoria, ya que nos enfrenta a poblaciones indígenas que por siglos vivieron sumidas en la atmósfera de sistemas religiosos complejos, y que a comienzos del siglo XVII aún continuaban practicando sus tradiciones ${ }^{2}$.

Hacia el 1600 las relaciones entre los hispanos y los ayllus locales eran indiscutiblemente estrechas, especialmente en Lima y Cuzco. La evangelización había avanzado aunque solo en apariencia. La realidad era bastante más compleja de lo esperado. Muchos grupos étnicos en alianza con los colonos hispanos procuraban atender a sus propios intereses, preocupados por la presión de los tributos monetarios, el trabajo forzado (mita minera) y los impuestos (Contreras y Glave 2002: 16). Vicios y virtudes europeas hubieron de calar hondo en el espíritu andino. Dinero, técnicas, especies vegetales y animales introducidos desde España igualmente habían modificado el espacio económico colonial. Por lo demás, hacía décadas que se venían fundando diferentes pueblos indígenas según los requerimientos de las reducciones, en las que parroquias e iglesias hicieron las veces de centros de poder y de control, mientras los encomenderos acumulaban mucho poder. El mestizaje biológico y cultural fue igualmente constante: la población blanca mezclada con la indígena había generado nuevos tipos fenotípicos y sociales e igualmente la población negra también aumentaba 
y algunos de sus integrantes se habían mezclado con blancos e indígenas. Además, la despoblación también había hecho su aporte a la deculturación, sobre todo en la Costa Norte y Central donde la crisis demográfica fue casi total; hombres, lenguas y sistemas culturales desaparecieron casi por completo (Cook 2005 y 2010). La corrupción eclesial también hacía, además, su aporte a la decadencia de la sociedad colonial especialmente en el área económica. Producto de estos acontecimientos se manifestaron inesperadamente en todos los rincones del mundo colonial varios conflictos teológicos y jurídicos que derivaron necesariamente en el ámbito de las tradiciones. Es en este relevante plano de la cultura colonial que los evangelizadores comenzaron a inmiscuirse en las actividades de los Yungas, fundándose por parte de la orden jesuita la localidad San Damián del corregimiento de Huarochirí hacia 1577, al que llegaría el joven sacerdote de menos de 25 años Francisco de Ávila (Cusco 1573?-Lima 1647), asentándose allí entre 1597 y $1609^{3}$.

La explosión de exaltación despertada por la campaña de contrarreforma que la Iglesia católica llevó adelante en Europa ${ }^{4}$, que Carlos V y Felipe II asumieron como una pesada carga para Castilla, generó en esta época las condiciones concretas para que miembros de la Iglesia Católica entrasen en franca colisión con comunidades supuestamente evangelizadas, especialmente en nuestra área geocultural de estudios. Esta situación de represión fue dolorosa y humillante para los Yungas, quienes comprendieron que los representantes de la Iglesia, como Francisco de Ávila y otros como él ( $v g r$. Hernando de Avendaño, Diego Ramírez, Rodrigo Hernández Príncipe), no detendrían los intentos por borrar de sus mentes y corazones la lógica mística de sus viejas tradiciones. El auto de fe que el cura doctrinante y luego vicario Francisco de Ávila leyó en Lima en 1609, época en que la jerarquía máxima se renovaba (el obispo Toribio de Mogrovejo había muerto y llegaba Baltazar Lobo Guerrero a reemplazarlo) también se iniciaba una nueva etapa de visitas eclesiásticas que darían paso a una forma conocida pero en una escala nueva: la extirpación de idolatrías. Lo que peligrosamente había quedado en evidencia era el hecho de que los indígenas evangelizados seguían desarrollando el culto a los ancestros y a ciertas deidades (como Libiac Cancharco), aun cuando se habían bautizado y participaban de las actividades parroquiales, situación que el joven
Francisco de Ávila aludía con la expresión: "se burlan de la religión cristiana" (Urbano ed. 1999: LVI). Aparecieron, por tanto, dos hechos clave: una parte de la población indígena seguía practicando sus ritos manteniéndolos en secreto, mientras que otra parte de esta población se mantuvo fiel a la religión cristiana. Esta situación dicotómica nos plantea la necesidad de realizar una interpretación más profunda en torno al pensamiento de sociedades de la Sierra Central, que podemos analizar gracias al Runa Yndio Niscap en las versiones de los traductores José María Arguedas y Gerald Taylor ${ }^{5}$.

La investigación "antiidolátrica" que inició Francisco de Ávila con el polémico y alarmante auto de fe en Lima, persiguió establecer los hechos, identificar las creencias "diabólicas" y registrar la información generada mediante entrevistados, interrogados e informantes, para un uso catequístico posterior. Esta práctica investigativa fue consustancial al proceso de extirpación de idolatrías: de tales documentaciones provienen gran parte de las informaciones que estudiamos acerca del mundo indígena previo a la conquista española ${ }^{6}$. Todo lo que interesó a los extirpadores quedó registrado gracias al soporte comunicativo oficial de la época: la escritura, que implicaba un lenguaje narrativo inspirado en el aristotelismo y el tomismo, una exégesis escolástica de la santa Biblia y la consideración de la literatura demonológica. Prácticas, objetos, tradiciones orales, mediante interrogador, traductor y escribano quedaron registradas por medio de la tinta y el papel en el soporte del texto y del archivo.

La autoría del manuscrito quechua de Huarochirí pertenece, según la hipótesis de Taylor (1987: 17; 1999: XIV-XV), basada en la expresión "DE la mano y pluma de thomas" (en el original margen derecha del f. 91r), a un sujeto que trabajó para Francisco de Ávila: el escriba Thomas, poseedor de una formación intelectual bilingüe, quien tuvo el talento y la habilidad suficiente para interpretar literariamente por medio del canal lingüístico quechua las tradiciones religiosas de los Yauyos. Esta situación era inédita en los Andes: un indígena había aprendido a usar los mismos instrumentos que los sacerdotes lingüistas habían creado para utilizar la lengua quechua (un idioma que carecía de la "letra de Dios") para vaciarla en el sistema de escritura alfabética. En este trance de la historia colonial la escritura y las relaciones ideológicas críticas entre el castellano y el quechua conformaron una 
afortunada alianza que generaron la posibilidad de que el sistema de creencias de los Yungas de San Damián de Huarochirí quedase para la posteridad (relativamente) a salvo del fanatismo destructor del fuego católico.

\section{El quechua y el castellano: traductores coloniales y traductores republicanos}

Para entender lo que nos enseña el Runa Yndio Niscap primero debemos reconsiderar qué fue lo que se destruyó en las campañas de extirpación de idolatrías, qué cosas fueron quemadas, destruidas y rotas; segundo, debemos entender qué significaban esos objetos ( $\rightarrow$ qué ritos sustentaban) en la lengua quechua. Es decir, debemos comprender qué fue lo que la escritura y el quechua misional hicieron con la cultura considerada "idolátrica", "demoníaca". Para obtener una imagen verosímil creemos firmemente que debe intentarse, provisionalmente al menos, comprender el modo esencial en que los andinos expresaban su cultura. Para crear/reconstruir esa imagen proponemos que la forma en que las etnias andinas expresaban su religión y cultura era mediante un sistema de signos complejo. Pues bien, a partir de esta hipótesis, que requiere una investigación futura, podemos entender de mejor modo el sistema de pensamiento que encierran textos como el estudiado aquí.

Las traducciones no son fáciles. Umberto Eco nos advierte: Traduttore tradittore. Acerquémonos a este asunto con cuidado. Los "dispositivos de registro" trabajan en al menos tres niveles fundamentales: a) "sistemas de ideas", b) "sistemas de comunicación", y c) traducción de lenguas A-B (en nuestro caso: quechua/castellano). Estos sistemas se han creado para conseguir la transmisión de ideas y pensamientos por distintos tipos de lenguaje que utilizan a su vez tipos de registros y soportes ${ }^{7}$. Nos interesan estos conceptos para poder trabajar con los dos conjuntos semióticos enfrentados en el siglo XVI, hecho cultural conflictivo del que uno salió triunfante: el modelo de la escritura y la historiografía. Los sistemas de ideas equivalen a las cosmovisiones de las diferentes culturas, en el tiempo y en el espacio. Las ideologías en este sentido conectan al hombre no solo con su prójimo y con la naturaleza sino también con lo sobrenatural y con el cosmos. Los sistemas de comunicación debemos entenderlos entonces como aquellas unidades integradas que permiten encapsular las ideas en tecnologías de registro, vehiculación y archivo de la información primaria oral. Para el caso de Occidente está claro que el sistema de registro que implica la escritura ha sido el recurso oficial de su cultura. Estos medios de la comunicación desde la Edad Media, especialmente a partir de la invención de la imprenta en Alemania (1454), crearon una cultura del libro que implicó la existencia de bibliotecas, talleres y escuelas donde se aprendía, entre otras habilidades, a leer y escribir. La España del Siglo de Oro, por ejemplo, representa una época brillante para la lengua castellana y la literatura, fenómeno cultural que eclosionó a partir de estas instituciones intelectuales y estéticas. Para otras culturas, no obstante, la cuestión de la escritura como fenómeno ideológico de la comunicación no existía. Las altas culturas de la América precolombina tuvieron, como hoy todos reconocemos, otros sistemas de comunicación que consiguieron eficientemente vehicular las ideas, los saberes y los conocimientos, consiguiendo establecer la expresión simbólica entre diferentes grupos étnicos, reflejando la tradición y el pensamiento.

En los Andes, postulamos, existió un sistema sígnico que conjugó varios subsistemas: junto a la lengua, canciones y poemas, música de distintos instrumentos ( $v g r$. pincullos, quenas, tinyas), bailes y coreografías, también textiles y vestuarios basados en el desarrollo de complejas y bellas iconografías abstractas o geométricas, así como también orfebrería y cerámica, en los que incluso los colores tuvieron significados con notables atributos simbólicos... Y para el caso de las sociedades andinas con Estado, la arquitectura, la ingeniería, y otros recursos mnemotécnicos complejos como los quipus, queros/ aquillas, pinturas, esculturas, murales..., fueron componentes principales de la cultura simbólica. Los mitos y los ritos -núcleo fundamental de los sistemas de pensamiento de las sociedades tradicionales nativas- fueron capaces de realizar representaciones alegóricas del mundo conocido para que los seres humanos pudiesen hacer de él un universo inteligible en donde las interacciones sociales pudiesen generar las condiciones necesarias para importantes desarrollos materiales y espirituales. A estos accesorios expresivos le llamamos "Sistema de Signos Andinos", y aunque no es el tema central de este estudio, lo consideramos fundamental para la comprensión del pensamiento indígena antiguo que realizamos desde obras textuales de factura indígena ${ }^{8}$. 
Pues bien, en el contexto de la traducción colonial que hacen los hispánicos de aquel mundo de habla quechua, surgen desde la república de indios pequeños grupos de individuos que formados a la sombra de los jesuitas, franciscanos o dominicos, encarnaron los dispositivos de registro que permitieron que la ecuación de traducciones quechua-castellano pudiesen realizarse del mejor modo posible, aunque enfrentando importantes problemas lingüísticos a nivel lexicográfico y semántico. La expertise político-lingüística española ya había concebido instrumentos adecuados para manipular el quechua, por ejemplo: la obra de Domingo de Santo Thomas [1560], la Doctrina Cristiana [1584] o la del jesuita anónimo [1586]. Diego González Holguín, por su parte, llevaba varios años estudiando el quechua y muy pronto se iba a imprimir su extraordinario Vocabulario [1608]. Por otro lado, ya hemos visto en nuestro estudio inicial sobre Titu Cusi Yupanqui ${ }^{9}$ cómo se crearon estos circuitos de la comunicación normalizada/estandarizada que arrastraron saberes y conocimientos a partir de individuos que lograron manejar ambas lenguas con destrezas relativas, errores inevitables, manipulaciones semánticas, con intereses ideológicos y sociales de distinto signo. Todos estos hechos tuvieron sus efectos políticolingüísticos en el primer siglo de dominación en los Andes, sin duda.

Así pues, es interesante recordar lo que el autor del Runa Yndio Niscap anotó en el principio del texto respecto de la tradición oral andina, la escritura occidental y las dificultades de nuevas nociones en la administración, orden y control de la memoria del pasado:

Si los indios de la antigüedad hubieran sabido escribir, la vida de todos ellos, en todas partes, no se habría perdido. Se tendrían también noticias de ellos como existen sobre los españoles y sus jefes; aparecerían sus imágenes. Así es, y por ser así y como hasta ahora no está escrito eso, yo hablo aquí sobre la vida de los antiguos hombres de este pueblo llamado Huarochirí, antiguos hombres que tuvieron un progenitor, un padre; sobre la fe que tenían y cómo viven hasta ahora. De eso, de todo eso, ha de quedar escrito aquí [la memoria], con respecto a cada pueblo, y cómo es y fue su vida desde que aparecieron (Arguedas 2012: 19).
Es interesante la reflexión del hipotético autor del manuscrito, porque quien realiza la crítica de este problema comunicacional fue un sujeto andino educado precisamente en la tradición cristianohispana. Es decir, fue un sujeto que aprendió el sistema alfabético de escritura, tecnología comunicativa "superior" que logró erradicar al "Sistema de Signos Andinos", lo que creaba interesantes puntos de vista en la construcción de un texto "objetivo", según la lógica que proporcionaba la ideología de la Iglesia colonial. En particular, este individuo andino expresaba en forma literal que la tecnología utilizada para escribir textos permitía no solo el registro funcional de las antiguas memorias y la historia mítica que encerraba, sino que además era válida para su archivo y conservación en el tiempo, asegurando su trascendencia histórica. También hacía la conexión con el mundo sobrenatural cristiano que aseguraba su conservación como parte de la Palabra de Dios, auxiliar de la Santa Escritura, eje ideológico hegemónico que englobaba la comunicación y la institucionalidad de la sociedad colonial.

Antes de proseguir el análisis, vale la pena contrastar algunas diferencias de la traducción anterior con la versión del Manuscrito de Huarochirí de Taylor. Tengamos en cuenta las diferencias léxicas y poéticas quechua y castellana que debían estar en juego en el mensaje codificado del texto indígena-cristiano:

Si en los tiempos antiguos los antepasados de los hombres llamados indios hubieran conocido la escritura, entonces todas sus tradiciones no se habrían ido perdiendo, como ha ocurrido hasta ahora. Más bien se habrían conservado como se conservan las tradiciones y ([el recuerdo de]) la valentía antigua de los huiracochas que aun hoy son visibles. Pero como es así, y hasta ahora no se las ha puesto por escrito, voy a relatar las tradiciones de los antiguos hombres de Huarochirí, todos protegidos por el mismo padre, la fe que observan y las costumbres que siguen hasta nuestros días. Enseguida, en cada comunidad serán transmitidas las tradiciones que se conservan desde su origen (Taylor 1987: 41-2; 1999: 5).

En esta versión encontramos diferencias lexicográficas importantes aunque su significado intrínseco 
expresa básicamente los mismos sentidos respecto de la problemática semántica. Para efectos de nuestra interpretación histórica esta expresión tan importante acerca de la "la oralidad y la escritura" nos ayuda en la tarea de valorar y evaluar la eficacia intercomunicativa de los grupos que se relacionaron desde varios ángulos de imposición de roles y funciones (del sistema oficial hacia el individuo castellanizado/quechuizado) en el complicado proceso de la evangelización y la lucha contra la "idolatría" que denunció la pervivencia de "peligrosas" tradiciones religiosas antiguas. Este asunto particular nos enfrenta con los cambios y transformaciones a nivel simbólico en la mentalidad de la población sujeta a las fluctuaciones de la religión permitida y de la "idolatría" proscrita, hechos que no nos deben hacer omitir los componentes materiales de los intereses en juego (posición, dinero, poder).

Estas dos traducciones modernas entrañan también un interesante debate que señala que si bien es cierto la primera versión de Arguedas es considerada actualmente como no tan exacta, revela por otro lado una poética particular del idioma quechua, con las inflexiones, imágenes y los recursos propios de esta lengua de morfología aglutinante. La versión de Taylor, en cambio, sería una versión más exacta desde el punto de vista de la traducción, pero pecaría a su vez de falta de sensibilidad, de frescura y de la originalidad propia de la lengua quechua y del hombre andino. Evidentemente, ambas versiones no consiguen traducir completamente el contenido del texto paleografiado por razones que los mismos autores reconocen dejando varias palabras y frases en la inevitable oscuridad. Con justicia debe señalarse que Taylor ha continuado con el perfeccionamiento de la traducción (Taylor 1999). Como ahora sabemos más detalladamente la lengua quechua de la época fue intervenida por expertos lingüistas de la Iglesia Católica, quienes desde mediados del siglo XVI utilizaron la que consideraron la "lengua general" quechua (o del Inca) para sus fines evangelizadores. Con este objetivo incluso intervinieron la propia historia de los Incas y la de otros pueblos andinos, como lo revelan las versiones historiográficas pretoledanas y toledanas ${ }^{10}$. Obligadamente en este punto tenemos que reconocer que el lenguaje quechua experimentó una notable transformación fonológica, sintáctica y gramática, en el paso del original verbal a su reemplazante colonial escrito (quechua misional). Formas y contenidos del quechua fueron modificados por la religión y cultura cristiana que logró apropiarse de ella fomentando un cambio ideológico formidable que redefinió imaginarios e identidades andinas, especialmente en el área de los arzobispados de Lima y de Cuzco.

Otra interesante discrepancia dice relación con la fecha de construcción del texto "antiidolátrico": 1598 (Arguedas) o 1608 (Taylor). Esta incógnita es importante no tanto desde el punto de vista bibliográfico o cronológico, sino substancialmente desde la emergencia de una población indígena educada tanto en las tradiciones hispanas como en las tradiciones andinas, yuxtaponiéndolas en una dialéctica cultural clave respecto de las hipótesis de nuestra investigación general ${ }^{11}$. Estas coyunturas sincrónicas nos muestran la emergencia inesperada de una cultura colonial dominante, pero integradora, que llevó a ciertos individuos a operar lenguas y culturas que enfrentaban desafíos y destinos distintos, creando las ambivalencias, contradicciones y ambigüedades acerca de las que hemos discutido a lo largo de esta investigación varias de sus facetas, inflexiones y características, creando una biculturalidad que enmarca varios problemas antropológicos como el del sincretismo, la aculturación y el mestizaje.

A partir de estas ideas podemos reconocer los problemas de traducción, de ideología e interpretación que encierran estos documentos de los que hacemos uso mitográfico. No menos importantes, insistimos, son las dificultades del reconocimiento de los sistemas religiosos enfrentados en la época colonial tocante a los contenidos, formas y simbolismos que estuvieron en juego en la tradición cultural a la que cada una correspondían.

\section{Mitos y ritos: la forma de la memoria en el mundo andino}

Internémonos ahora en el mundo religioso de la Sierra Central, desde donde emergieron conflictos de poder y luchas por la sobrevivencia cultural. En este caso debemos destacar las relaciones teóricas inseparables entre mito y rito, así como el de los universos simbólicos propios de las dos culturas en juego. Como sabemos gracias al estudio de las religiones comparadas, el rito corresponde a un acto religioso-ceremonial estrictamente pautado, de naturaleza simbólica, con cualidades culturales particulares; algunos de estos ritos son: propiciatorios, funerarios, matrimonios, nacimientos, coronaciones, etc. El mito, en tanto, podemos entenderlo como un 
relato tradicional que refieren hechos de seres asombrosos que en un pasado fundamental instauraron las bases ideológicas de las sociedades, determinando sistemas de ideas que encuentran su correlato en la tradición oral y en los soportes materiales de la comunicación simbólica. El mito reflejó al rito históricamente (y viceversa). El poder político y la autoridad religiosa, pilares del poder, fueron los factores que determinaron estos elementos del pensamiento humano en sociedades occidentales y no occidentales, con notables diferencias cada cual. Podemos ver que las ceremonias y celebraciones encabezadas por las comunidades, en su afán por rendir homenaje y mantener relaciones fomentadoras con la naturaleza y con los ancestros -el mundo de los muertos-, crearon y organizaron un conjunto ordenado y lógico de creencias y costumbres para mediar entre lo humano y lo sobrenatural.

En el mundo andino antiguo sociedad, economía, religión y política se articularon racional y espiritualmente para explicar la vida en general. La agricultura, la ganadería, las relaciones de parentesco, las nociones de geografía y ecología, la concepción de poder, así como el conocimiento del clima, de la flora y fauna, el culto de las presencias divinas y los conocimientos astronómicos, conjugaban el saber y el conocimiento de estas sociedades que vivieron un tiempo sagrado marcado por la tradición antigua. Por tanto, las cosas y los objetos en torno a los hombres fueron deificados, sacralizados, eternizados. Este hecho ante los ojos de los colonos cristianos generó la idea falsa de que los andinos practicaban "idolatrías". En el Runa Yndio Niscap encontramos algunas referencias interesantes a los "ídolos", como fueron denominados peyorativamente por los sacerdotes de la colonia las representaciones líticas o metálicas o de materiales naturales (maderas, pieles, conchas...), a los objetos simbólicos que materializaban el universo de las creencias imaginales. A continuación vamos entonces a analizar aspectos de la cosmovisión religiosa de dos deidades de la Sierra Central.

Los “ídolos". Como se señala literalmente en el inicio mismo del Manuscrito Quechua, fue en épocas antiguas, en el período llamado Asentamientos Locales Pre-Incas ( $c a$. siglos XI-XV dC.), en sitios arqueológicos como Chuycoto, Suni, Warirumo y Chaca, que: "En tiempos muy antiguos existió un huaca llamado Yanañamca Tutañamca. Después de estos huacas, hubo otro huaca de nombre Huallallo
Carhuincho" (Arguedas 2012: 21). En primer lugar deseamos destacar un asunto relativo a la traducción quechua/castellano. Para Arguedas, a quien vamos siguiendo en su labor de traducción, existió solo una huaca: "Yanañamca Tutañamca". Sin embargo, luego pluraliza a la deidad. Si bien resulta ambiguo el enunciado traducido, nos quedamos con que la deidad era solo una. La solución final podría ser que esta figura sobrenatural posea dos componentes o atributos, que representen una síntesis. Con todo, cuando consultamos la versión de Taylor (Taylor 1987: 45) nos encontramos con que efectivamente para este autor se trata de dos huacas, en la que cada cual responde a su nombre singular: Yanañamca y Tutañamca. Intentaremos tomar una postura en cuanto a este tema y otros similares a lo largo de este ensayo. Establezcamos por mientras que estas deidades fueron creación de sociedades que vivieron en un marco agrario y tribal, sujeto por tanto a las fluctuaciones de la religión, organización parental, el territorio y la producción económica, y probablemente trabados en una interacción intertribal guerrera constante.

De nuestra lectura deducimos que es a fines de aquella época que se generó una lucha ideológica entre deidades tutelares que culminó con la aparición y el triunfo de otra entidad sobrenatural llamada Huallallo Carhuincho, quien se impuso sobre las anteriores huacas, posiblemente produciendo cambios en el sistema de ideas y también en la jerarquía de estos grupos tribales. Según podemos inferir, es la cuestión del control del territorio y del agua disponible para el regadío lo que movió a estos grupos a proponerse nuevas y mejores posibilidades de producción agrícola y ganadera. Esta deidad impuso, siguiendo al texto, que los hombres solo tuviesen dos hijos, uno de ellos podía vivir trabajando para el bienestar de la comunidad, mientras que el otro sería "devorado" por la deidad, esto es: sacrificado en un ritual de muerte (Qhapaq Qocha). Es interesante que a raíz de estas informaciones surjan dos datos con distinto valor. El primero dice relación con los ritos de muerte; a raíz de estos decesos naturales existió la creencia de que los difuntos revivían a los cinco días de haber fallecido. En tanto que la segunda información relacionada con este hecho señala que las tierras de cultivo maduraban a los cinco días de su sembradío. Estos datos son interesantes pues indican una relación con números (el cinco $\rightarrow$ en quechua: pishqa) o períodos particularmente favorables para las actividades religiosas 
y económicas. Hay otros ejemplos de este tipo que relevaremos en su momento.

Se menciona en esta primera parte que los Yungas, entendiendo por tales tanto a etnias como a tierras cálidas, "aumentaron" y se "multiplicaron": tuvieron éxito en sus actividades económicas, resultando de ello un aumento de la densidad demográfica, lo que sin duda evidencia la salud de estas sociedades. Sin embargo, la vida material de estos grupos étnicos realmente no mejoró, pues, según indica luego la traducción, "vivieron miserablemente" en aquella época: "hicieron chacras, escarbando y rompiendo el suelo" (Arguedas Op. cit.). El traductor utiliza un recurso que vinculaba la narración al mundo natural de los animales, en este caso se refería a dos aves: "huritu" ("lorito", dice Taylor Op. cit.) y "caqui" (especie desconocida), hermosos pájaros amarillos y rojos. En la traducción de Taylor (Taylor 1987: 49) tanto los hombres como las aves -ambas obras de Huallallo Carhuincho- fueron expulsados por Pariacaca a la región de los Anti (el Este).

En resumen, tenemos que esta fase cultural culmina hacia fines del primer milenio d.C., con la siguiente secuencia del predominio de huacas: Yañamca Tutañamca-Huallallo Carhuincho/Cuniraya Huiracocha-Pariacaca, de la más antigua a la más reciente, es decir, desde el período Asentamientos Locales Pre-Incas, pasando por el Período Inca, o "Ñaupa Pacha" tiempo de los "Machoncuna", hasta la época cristiana colonial en que se escribió el manuscrito quechua (1598 o 1608). Esto es interesante porque visto esquemáticamente estas informaciones nos ilustran respecto de las luchas intertribales que se debieron de haber dado en el tiempo entre diferentes grupos étnicos, los que pretendieron imponer sus principios sociales por el control de las tierras y las aguas, y del manejo de estas en el ciclo productivo.

En la narración se indica finalmente que con el tiempo apareció otro huaca, llamado Pariacaca. A su arribo, esta deidad expulsó a todos los hombres que se le opusieron; es decir, en el conflicto un grupo predominó sobre el otro, variando la situación de preeminencia de las deidades. De igual modo, el Manuscrito Quechua nos habla también de Cuniraya Huiracocha. Este personaje evidentemente parece ser una advocación más de Wiraqocha, de antigua presencia panandina. Así planteadas las cosas, los huacas Pariacaca y Cuniraya fueron contemporáneas. El autor de la narración, el escribano Thomas, hace una interesante observación de tipo cronológica al no lograr establecer si esta deidad fue anterior o simultánea a la aparición de Pariacaca. Aún más, hace la distinción entre su entidad básica y su relación con Wiraqocha. Sabemos que este es un ser sobrenatural panandino; el autor le llama "creador del hombre" (Arguedas Op. cit.), posiblemente influenciado por los evangelizadores que emplearon esta fórmula, entre otras, para establecer equivalencias religiosas. A nosotros nos parece que estas deidades tuvieron que existir simultáneamente en el imaginario religioso de los andinos, debido a que el antiguo sistema de creencias tuvo la cualidad de mantener una pluralidad de deidades y formas sagradas que coexistieron en el tiempo sagrado (no hay "monoteísmo" ni hay "panteones"). Pero debemos buscar razones más de fondo para lograr explicar la percepción que los serranos tuvieron acerca de esta deidad. Para los Incas, por ejemplo, Teqse Wiraqochan Pachayachachic fue una de las presencias más importantes del espacio religioso cuzqueño (Itier 2013: 29 y ss).

Según estas informaciones, la gente le adoraba diciendo la siguiente fórmula: "Cuniraya Huiracocha, hacedor del hombre, hacedor del mundo, tú tienes cuanto es posible tener, tuyas son las chacras, tuyo es el hombre: yo" (Arguedas Op. cit.). Cuando los Runa realizaban trabajos difíciles lo adoraban y arrojaban hojas de coca al suelo, diciendo: "Haz que recuerde esto, que lo adivine Cuniraya Huiracocha" (Op. cit.). Estos hombres antiguos adoraban a Wiraqocha, ser invisible. Como el documento señala, la existencia de la deidad Cuniraya asociada a Huiracocha fue fundamental para la gente de esta área de la Sierra Central. Se dice que especialmente fueron los tejedores de las comunidades quienes más creían en las habilidades fomentadoras de las labores de creación de textiles, tarea esencial y labor prestigiosa que requería de mucha atención y cuidado, ya que en aquellas piezas textiles los especialistas fueron capaces de transmitir significados de alta importancia social en sus códigos simbólicos.

La problemática relación Cuniraya/Huiracocha, arroja varias interrogantes: ¿se trata de dos huacas? o ¿ambos se fusionaron?, ¿qué implica cada posibilidad? Aparentemente, grupos étnicos distintos poseyeron diferentes formas de percibir a sus deidades. Incluso cuando de Wiraqocha se trata, los Incas tienen una interpretación propia. En cuanto a los otros grupos étnicos, sabemos que los Incas respetaron las creencias en otras deidades o particulares percepciones de tales deidades: lo sagrado 
se expresaba desde lo múltiple. Para explicar esta y otras cosas, realizamos a continuación nuestra interpretación sobre la deidad "Cuniraya Huiracocha".

Vida de Cuniraya. Para abordar este apartado vamos a recurrir a la traducción de José María Arguedas. El Runa Yndio Niscap dice literalmente: "Este Cuniraya Huiracocha, en los tiempos más antiguos, anduvo, vagó. Tomando la apariencia de un hombre muy pobre; su yacolla [manto] y su cusma [túnica] hechos jirones" (Arguedas 2012: 23). La referencia nos invita a imaginar que la deidad en un pasado remoto tuvo un carácter errante. Esta cuestión nos sugiere razonablemente que la deidad fue un peregrino (en quechua $\rightarrow$ llacta llactacta puric) que realizaba sus periplos en razón de su naturaleza particular. El lenguaje simbólico del mito sugiere también la posibilidad de que la deidad tuviese ciclos de participación en la vida de las comunidades andinas. El hecho de que la deidad haya cobrado la apariencia de un hombre pobre, ataviado de prendas viejas y harapientas, insinúa la posibilidad de que el ser divino jugaba a transformarse según el tenor de las situaciones en las cuales el personaje intervenía en sus interacciones con los seres humanos (Rostworowski 2007: 29 y ss).

Una de las escenas más sensibles y poéticas del Manuscrito Quechua de Huarochirí es el mito que relata la relación de Cuniraya con una Ñusta (hija de Curaca), una figura humana que se transformará luego en deidad que se integrará finalmente al sistema religioso. En esta narración el comportamiento que poseía la divinidad resulta ejemplar, pues representa un arquetipo. La Nusta es también una huaca, por lo que la escena es sobrenatural si bien expone una relación obviamente humanizada (la concepción "inmaculada" del bebé que ambos van a procrear). Señala el texto: "Y así, en ese tiempo, había una huaca llamada Cavillaca. Era doncella, desde siempre" (Arguedas 2012: 23). Como sabemos, en el ámbito divino de las deidades y los ancestros estas figuras míticas tenían también un contexto de interacciones e interdependencias que explicarían los fenómenos naturales y sobrenaturales, lo que concede lógicas religiosas específicas ( $v g r$. nacimiento, muerte) que explican aspectos materiales de la existencia de los antiguos hombres andinos. La cualidad de ser doncella (virgen) le concede al relato una cierta influencia cristiana en su obvia relación con la imagen de la Virgen María, madre de Jesucristo -fecundada por Dios-. Pero la estructura general del documento profundiza esta relación entre una deidad poderosa que "juega" con los otros seres al transformarse según su carácter travieso (en hombre pobre o en figura animal) y la deidad femenina que posee igualmente un firme carácter al pertenecer a una élite sagrada representando el poder de su persona y su linaje, y siendo la madre fecundada por la importante deidad. Todo esto crea un marco de dramatismo simbólico bastante abstracto desde el punto de vista de la utilidad del mito en el marco de la sociedad que conocía, utilizaba y reproducía el relato.

\section{Cavillaca}

Cierto día se puso a tejer al pie de un árbol de lúcuma. En ese momento Cuniraya, como era sabio, se convirtió en pájaro y subió al árbol. Ya en la rama tomó un fruto, le echó su germen masculino e hizo caer el fruto delante de la mujer. Ella, muy contenta, tragó el germen. Y de ese modo quedó preñada, sin haber tenido contacto con ningún hombre. A los nueve meses, como cualquier mujer, ella parió así doncella. Durante un año crió dándole sus pechos a la niña. “¿Hija de quién será?”, se preguntaba (Ibíd.).

No podemos sino sospechar de la concepción inmaculada mediante la que Cavillaca quedó embarazada. El hecho de que Cuniraya convertido en pájaro utilizara un fruto en donde depositó su semen, hace que la relación sea sobrenatural. Al tratarse de un registro que captó la tradición oral en un texto escrito no nos queda sino reconocer los extremos críticos de la intervención de la ideología cristiana en los antiguos modos de pensamiento de la mentalidad andina. Lo interesante, por otro lado, es que la identidad del padre fecundador queda en el misterio absoluto, esto genera en el relato el desarrollo posterior de la historia de un engaño, de una equivocación, de una huida y un suicidio. Repasaremos a continuación los hechos relatados en el orden que sigue el texto y trataremos de hacer nuestra interpretación como propuesta analítica tentativa.

Cavillaca fue una huaca que vivió en un lugar llamado Anchicocha. Fue un ser femenino que vivió en una situación jerárquica de élite pues era una ñusta, una mujer noble y hermosa, pero orgullosa 
y soberbia: representaba posiblemente los valores de las clases dominantes y entrañaba valores de predominio y poder religioso y político, así como el vínculo místico con las fuerzas de la naturaleza. Al ser mujer tenía un lugar y una función que la ligaba con deidades y fuerzas vinculadas a la tierra, al agua, los alimentos, la sexualidad y la reproducción. Por su parte, Cuniraya Huiracocha era una deidad antigua y prestigiosa que dominaba a las deidades de la costa, la sierra y la selva. Su historia mítica lo sitúa hacia el final del período autónomo en la cúspide del sistema religioso de los Incas, por ello su nombre era prestigiosamente inclusivo: Teqse Wiraqochan Pachayachachic, prestigio que compartía con Inti, Illapa, Quilla, y otros. En nuestro texto, Cuniraya encarna a un ser poderoso que tiene cualidades mágicas que le permiten interactuar con los seres humanos. Su comportamiento era una mezcla de ironía y engaño, pues se trataba de un burlador. Pero lo era también trágico y melancólico. Un ser difícil de asir, como se puede ver. En la escena que estamos comentando, Cuniraya se había convertido en pájaro y luego se disfrazó de pobre para interactuar con la mujer que llegó a amar. Al conocer a la huaca Cavillaca, la deidad decide fecundarla para concebir un nuevo ser. Cuniraya embaraza a Cavillaca. De la unión nace su hijo/a. Aunque no se dice explícitamente, asumiremos que nace un bebé de sexo femenino lo que explicaremos más adelante.

Al pasar el tiempo, Cavillaca decidió averiguar la paternidad de su hija. Para ello decidió reunir a todas las huacas masculinas. En el momento de la reunión, que podemos imaginar tuvo lugar en las alturas cordilleranas, todas las deidades masculinas acudieron pues la deseaban como pareja divina. Este deseo era tal que estaban dispuestos a mentir al momento de reconocer al bebé de Cavillaca. Estas deidades acudieron con sus mejores trajes, aparecieron particularmente ostentosos, eran grandes huacas que poseían mucho poder, poseían bellas vestiduras. La madre decidió que sería el propio bebé quien lograría identificar y reconocer a su padre. En esta escena hubo una deidad que destacaba, pero por razones diferentes a las del resto: se trataba de Wiraqocha quien llegó luciendo como un viejo pobre y menesteroso. Era, desde luego, Cuniraya que venía disfrazado. En este hecho también observamos una función simbólica especial. Su intención podría ser la de burlar a la madre que le pareció admirable aunque engreída.
(En esta situación debe buscarse el significado y la intencionalidad del lenguaje mítico. Si es correcto que representan arquetipos entonces tenemos tipos ideales de comportamiento.) En tanto, el bebé gateó y se dirigió hacia el viejo harapiento. Reconoció en él a su verdadero padre. Cavillaca ante este hecho irrefutable se horrorizó, ya que detestó la idea de haber sido embarazada por aquel viejo pobre. No sabía que se trataba de un engaño de Cuniraya Huiracocha. Actitud radicalmente diferente si la huaca hubiese sabido quién era en realidad el padre de su bebé. Se descubre la paternidad del bebé de Cavillaca y Cuniraya, lo que generará el desenlace posterior. Cavillaca huye del "pobre" Cuniraya hacia la costa, llevándose consigo a la hija de ambos. Cruza la distancia de la sierra a la costa. Al llegar a las playas de la Qochamama, Cavillaca se arrojó a sus frías aguas junto con su bebé. Ese es el fin de ambos personajes, fin del que Cuniraya era en parte responsable. En el lenguaje simbólico del mito este "hecho" se materializa y se vuelve "verdadero". El sistema de creencias creó un sentido alegórico que poetizaba y mitificaba la muerte de ambas: los cuerpos hundidos se transformaron en los roqueríos que se veían frente al templo de Pachacámac. En fin, el engaño de Cuniraya y la altivez de la huaca crearon este final.

Luego de este hecho entendemos que se ha generado una ruptura narrativa. Así, luego de las desapariciones de Cavillaca y su hija convertidas ahora en rocas del mar, es decir, habiendo pasado a ser parte del reino de la madre-mar, prosigue la historia de esta deidad trickster. A sabiendas de que la huaca y su hija huyeron hacia la costa, Cuniraya decide ir en busca de su amada Cavillaca y su hija. En su camino hacia la costa, Cuniraya se encontró con ciertos animales que lo conducían (o alejaban) hacia su esquiva amada. Unos lo animaban a continuar y darle alcance, mientras que otros lo desanimaban en su búsqueda. Comentaremos a continuación este interesante trazo del mito cargado de simbolismos totémicos.

Veamos. Primero fue el cóndor (+) quien le dice a Cuniraya Viracocha, en su trayecto de la sierra a la costa, que estaba cerca de alcanzar a la ñusta Cavillaca y a su hija. En segundo término, apareció en su camino el zorrino (-), quien le señaló que no podría alcanzarla. En tercer término, asomó el puma $(+)$, quien le animó a continuar en su búsqueda. En cuarto término, apareció el zorro (-), quien tampoco le dio esperanzas de darle alcance a Cavillaca. En 
quinto lugar, fue el halcón (+) quien se le apareció, señalándole que podría dar con la madre y la hija si se apuraba. Y en último lugar, sale a su camino el lorito (-), ave que le dijo que su búsqueda sería inútil. Esta "fauna sagrada" andina, como la percibe Luis Millones (Millones 2012: Cap. 1), nos permite ingresar en un imaginario que le asigna cualidades y valores a los animales referidos que poseen, por lo tanto, un conjunto de significados religiosos. De acuerdo con esta interpretación que marcamos con dos signos [(+) y (-)], indicando favorecimiento y obstrucción, podemos hacer el siguiente acercamiento: al adjudicarle el Runa Yndio Niscap propiedades positivas y negativas a estos seis animales aprendemos que la valoración que se les asignaba creó una relación entre estos y las sociedades étnicas que los utilizaron para explicar las complejidades de la lucha ideológica-religiosa que podría suponer la predominancia de ciertos mitos sobre otros, es decir, de unas sociedades sobre otras. El antropomorfismo y el zoomorfismo crearon relaciones simbólicas que daban un valor especial al sistema de parentesco y a la identidad étnica. Tal valor concedía prestigio y significado mágico a este vínculo entre cultura y naturaleza. Así, el cóndor, puma y halcón poseían un valor positivo para estos grupos étnicos. Mientras que el zorrino, zorro y lorito poseían cualidades que no eran valoradas por la sociedad. Cuniraya Huiracocha premiará y castigará a unos y otros en su búsqueda de Cavillaca y su hija, que fueron finalmente víctimas del engaño y de la soberbia.

Cuniraya llegó finalmente a Pachacámac, la huaca más importante de la costa Central, donde se encontró con Urpayhuachac y sus dos hijas. Allí es testigo de cómo su amada y su hija han terminado su viaje convirtiéndose en roqueríos marinos. Aquí emerge otra ruptura narrativa. Aparecen otros personajes sobrenaturales que producen una bifurcación en el relato. Cuniraya intentó acostarse con una de las hijas de la deidad Urpayhuachac. La madre de estas niñas se enteró y se enfureció con él. Se genera otra situación de conflicto creada por Cuniraya. Esto demuestra que esta deidad tenía un comportamiento ambiguo. Por otro lado, esta mujer criaba peces en un pequeño pozo. En esta época no había peces en el mar. Cuniraya al botar las pertenencias de Urpayhuachac en el gran lago fue responsable de que los peces se multiplicasen. De esta relación podemos deducir la unión estrecha entre el propio Wiraqocha y la Qochamama. Recordemos que el teónimo Wiraqocha tiene un vínculo semántico con el mar (y con todas las aguas del cosmos) ${ }^{12}$. Este dato nos permite aproximarnos un poco más al origen costeño (o acuático/líquido) de esta deidad ${ }^{13}$. También queda reverberando en nuestra reflexión el vínculo cultural de las sociedades serranas con las costeñas. Finalmente, Cuniraya anduvo por la orilla del "gran lago", triste y solitario. Urpayhuachac, en tanto, intentó engañarlo para arrojarlo en un gran precipicio, pero este escapó engañándola nuevamente... Cuniraya volvió a Huarochirí o Anchicocha, y allí siguió engañando y burlando a los hombres de los pueblos.

Prodigios de Pariacaca. Para abordar este apartado vamos a recurrir ahora a la traducción de Gerald Taylor (Op. cit.). En el siguiente segmento del Manuscrito Quechua que comentaremos se relata el origen y la aparición de la deidad Pariacaca. Esta deidad, según se indica, tuvo su nacimiento a partir de cinco huevos. Esto ocurrió en el cerro Condorcoto. Como sabemos, esta deidad aparece como la más importante en las épocas Inca y colonial. Desde el punto de vista físico tenemos a esta figura sagrada que quedó vinculada al apu nevado que lleva su nombre propio: el santuario Pariacaca, situado entre 5.730 y $5.750 \mathrm{msnm}$.

Para comenzar, creemos que resulta muy interesante reconocer los problemas de cronología que el individuo responsable de este texto, el escribano Thomas, tuvo al tratar de identificar, según las categorías temporales aprendidas de los europeos, los tiempos pasados de esta región cultural. Señala que "no sabemos cuál fue el origen de los hombres de aquella época ni de dónde provenían" (Taylor 1987: 85). Expresión que nos revela las dificultades que enfrentamos al estudiar el mundo andino: pues no solo no existió en los Andes un sistema de escritura como el occidental que permitiese la existencia de documentos y archivos, sino que tampoco existió en los Andes un sistema cronológico calendárico, como el de números latinos o árabes usados en Occidente ${ }^{14}$. Pero esta situación no es aquí antropológicamente atingente. Lo que sí podemos vislumbrar aplicando un análisis mitográfico es que uno de los patrones de comportamiento más recurrentes de estas sociedades fue el de luchas interétnicas, en las que los grupos familiares emparentados luchaban entre sí por alcanzar sus objetos de control de la tierra y del agua de regadío enfrentando a otros grupos rivales, obteniendo estos medios de 
producción para fines agrícolas y ganaderos. Estas luchas y sus resultados dejaron tras de sí una huella mítica que explicaba el poder de las divinidades. Sus ideologías proporcionaron a estos grupos humanos los argumentos naturales y sobrenaturales adecuados para llevar a cabo sus metas y conseguir el triunfo imponiendo su sistema tradicional de vida. El Manuscrito Quechua nos dice que estas luchas estaban encabezadas por "curacas valientes y ricos". De este modo: "los hombres que vivían en aquellos tiempos no hacían otra cosa que guerrear y luchar entre sí, y reconocían como sus curacas solo a los valientes y a los ricos. A estos llamamos los purum runa" (Taylor 1987: 85). El extirpador Francisco de Ávila, por otro lado, hace la analogía manipulada desde su punto de vista dogmático, y señala que esta época fue aquella de "....antes de aquel diluvio...". Como vemos, las interpretaciones son variadas y siempre arbitrarias. Nos interesa, empero, la idea de "purum runa" que podemos entender como la época antigua anterior incluso a la hegemonía incaica sobre el Chinchaysuyu. La presencia de Pariacaca corresponde aquí, como culto predominante, precisamente a una época anterior, entre el colapso de las sociedades Wari / Tiwanaku y el inicio del desarrollo de la etnia incaica (siglos XII-XIII aprox.) (Bauer 2011).

Decíamos que Pariacaca nació de "cinco huevos". El texto señala: "/Sabemos/ que en aquella época, Pariacaca nació de cinco huevos en el cerro de Condorcoto" (Taylor 1987: 85). Este "nacimiento" lo tenemos que vincular con las luchas tribales entre aquellos que confiaron en este paradigma emergente y en los antiguos habitantes de estas tierras que a su vez habían confiado en la deidad Huallallo Carhuincho. Evidentemente la derrota de esta deidad por Pariacaca tuvo que generar una reestructuración de las jerarquías y hegemonías étnicas en la Sierra Central. Sin duda alguna aún queda mucho por investigar arqueológicamente respecto de este antiguo lugar. Esta deidad tuvo un hijo llamado Huatyacuri: "Un solo hombre, un pobre que se llamaba Huatyacuri, quien era también, según se dice, hijo de Pariacaca, fue el primero en ver y en saber de este nacimiento" (Taylor 1987: 87). Según podemos constatar, este ser (héroe cultural) pudo atestiguar el surgimiento de esta poderosa deidad que guió a su pueblo a un nuevo desarrollo o hacia una nueva expansión. La vida de Huatyacuri, necesariamente azarosa y llena de peripecias, lo enfrentaba con los antiguos detentadores del poder. En este sentido, este personaje conjugaba simbólicamente las situaciones generadas por las luchas ideológicas, étnicas y territoriales. Es interesante notar desde el punto de vista del estudio de la religión andina las peculiaridades de las creencias de una sociedad no estratificada, que basaba su desarrollo en el nivel tribal y territorial. Las luchas interétnicas marcaron el devenir de las creencias religiosas. Y el poder casi siempre tiene su correlato con la hegemonía de la deidad, los espíritus de los ancestros o de la huaca. Así, Huatyacuri al ser hijo de Pariacaca mediante portentos e intervenciones debía preparar la venida de la deidad (otro interesante paralelo con el cristianismo). En este plan divino enfrentó a un "falso dios" llamado Tamtañamca.

Según nos expone el texto: "Había entonces un hombre llamado Tamtañamca, un muy poderoso y gran señor" (Taylor 1987: 87). Su casa quedaba en Anchicocha. Sucedió que este extraño personaje poseía un cierto poder que logró imponer al resto de los miembros del grupo Yunga, haciéndose obedecer por todos. Su poder se expresaba en el texto por propiedades casi mágicas. El techo de su casa estaba hecho de plumas de pájaros, según se dice (Tamtañamca era una zorra muerta hecha de oro situada en un cerro, según anotaciones de Ávila, dato que debemos mantener presente). Por demás, "Poseía llamas amarillas, rojas y azules, es decir, de todas las variedades imaginables" (Taylor 1987: 87). Este hombre era un engañador, creíase un gran sabio y una deidad; su "poder" lo hacía respetado por la comunidad. Pero Tamtañamca contrajo una mortal enfermedad que lo consumía lentamente. Si bien sabemos cuál era el origen de esta enfermedad (tres animales monstruosos), lo interesante es que a pesar de que no se dice explícitamente en el Manuscrito Quechua, estas criaturas estarían cumpliendo la función de castigar al falso huaca.

Las historias de ambos personajes se van anudando en la medida en que la narración progresa. El hijo de Pariacaca se aprontaba a cumplir con la misión que su padre recientemente nacido le había encomendado. De acuerdo con el relato: "Huatyacuri, que en aquel tiempo estaba viniendo del mar, subió al cerro que bajamos cuando vamos a Cienaguilla. Allí se adormeció" (Taylor 1987: 89). El cerro mencionado es el Latausaco. En este periplo iniciático el peregrino Huatyacuri, al despertar en algún lugar del paisaje montañoso, escuchó sigilosamente la charla de dos zorros acerca de la enfermedad de un hombre llamado Tamtañamca. Según pudo 
entender, la enfermedad se debía a que un grano de maíz había tocado a su mujer. Este grano se lo había dado a un hombre que no era su marido. La mujer tuvo una relación sexual con aquel hombre, cometiendo adulterio. Producto de esta situación se había creado un maleficio sobre Tamtañamca (lo que aparece como un castigo [nótese el valor semántico e ideológico de estas dos expresiones: "maleficio" y "castigo"]). Según se explica, en la casa de este personaje había dos serpientes que se lo estaban "comiendo"; estaban ocultas en el techo de su rica casa. También había un sapo de dos cabezas escondido debajo de su batán. Ambos animales nefastos estaban matando al hombre que se creía una deidad. Tal era el maleficio que se había cernido sobre él por la relación sexual adúltera que cometía su mujer. Esto era lo que charlaban los zorros. Y de esto también se enteraba el que habría de preparar la venida de su padre. Desde el punto de vista del análisis simbólico, estos animales encarnaban dos cualidades que los hacían especiales según los Yungas: eran astutos, sigilosos y malcriados. Al escuchar esta conversación Huatyacuri se apropiaba de las cualidades divinas de los zorros. Se especifica en el mito estudiado que un zorro era de arriba (de las alturas montañosas) y el otro zorro era de abajo (de los valles, de las pampas). Comentemos este asunto con más detalle.

El zorro de abajo le comenta al zorro de arriba que una de las hijas de este hombre además estaba enferma por un pene (¿un enamoramiento perdido?), según literalmente se expresa en el texto. "Mientras conversaban, Huatyacuri escuchaba todo lo que estaban diciendo" (Taylor 1987: 93) y urdía la utilidad de lo que oía. En efecto, este hombre tenía una hija cuyo nombre era Chaupiñamca, la que estaba "enferma de amor"... Así es que el hijo de Pariacaca se puso en marcha hacia el pueblo donde mandaba este hombre. Llegado al pueblo preguntó quién estaba enfermo a pesar de que bien lo sabía, aparentando sagazmente ignorancia. La hija del hombre, llamada Chaupiñamca, le respondió que era su padre. Así como en el mundo de los hombres se forman parejas, lo que es un principio elemental del pensamiento andino antiguo (la dualidad, la complementariedad), del mismo modo al conocerse Huatyacuri y Chaupiñamca se crea, deducimos, un vínculo que los enlazará en lo que viene.

Curiosamente el hijo de Pariacaca, así como en el caso de nuestro ya comentado Cuniraya Huiracocha, era también un ser pobre. Este comportamiento (ataviarse humildemente) posiblemente está relacionado con los valores de humildad, austeridad y colectivismo que fueron idealizados como esenciales por las antiguas comunidades de los Runacuna. Al revelar que él podía curar a Tamtañamca, los cercanos a este personaje se echaron a reír, dudando de sus capacidades, ya que lo veían a él como un pobre harapiento, un Peregrino. Lo que ellos no sabían es que Huatyacuri no solo era hijo de la deidad Pariacaca, sino que también tenía poderes extraordinarios como el que le permitió acceder a la información que solo los zorros podían conocer. De este modo:

Los sabios, que estaban allí, cuando escucharon sus palabras, se echaron a reír y dijeron: “¿Estaríamos nosotros aquí curándolo, si un pobre como este fuera capaz de hacerlo?". El señor enfermo, sin embargo, deseaba ante todo librarse de su enfermedad e hizo llamar [a Huatyacuri]. "iQue venga cualquiera [que se diga capaz de curarme]!, les dijo" (Taylor 1987: 95).

Huatyacuri ofreció sanarlo a cambio de su hija. Lo que ciertamente hizo que el marido de la hija mayor (hermana de Chaupiñamca) se pusiera furioso. A la larga, esta situación creará una lucha entre este hombre y Huatyacuri, que luego comentaremos. En cuanto a Tamtañamca:

\begin{abstract}
Huatyacuri empezó a curar [a Tamtañamca]. "Padre", le dijo, "Tu mujer es adúltera. Su culpa te ha hecho enfermar. Encima de tu casa tan espléndida hay dos serpientes que te están comiendo. Y hay también un sapo de dos cabezas debajo de tu batán. Tenemos que matarlos a todos para que te cures. Cuando ya te hayas curado, tendrás que adorar a mi padre por encima de todo. Solo pasado mañana nacerá. En cuanto a ti, tú no eres auténtico animador de hombres. Si lo fueras, no te habrías enfermado de esta manera." Al oír sus palabras, [Tamtañamca] se espantó (Taylor 1987: 97).
\end{abstract}

Esta situación revelada generó una tensión máxima entre los personajes involucrados. La mujer se enfureció y negó la acusación. El enfermo mandó desde luego a destruir las casas. Sacaron a las dos serpientes y al sapo de dos cabezas, y eliminaron a 
los animales que consumían al falso "gran sabio". El maleficio cesó su maligna influencia gracias a Huatyacuri. Ante la evidencia que desengañó al enfermo la mujer tuvo que reconocer su infidelidad. Luego, el enfermo pudo sanar. Entonces tuvo que cumplir con la palabra de adorar a Pariacaca, tal como Huatyacuri exigió. En este contexto aún quedaba por concretarse la unión entre Huatyacuri y Chaupiñamca, la hija de Tamtañamca, lo que creó el enfrentamiento entre el hijo de Pariacaca y el esposo de la hermana de Chaupiñamca. El hombre, luego de su recuperación, le dio a su hija. Juntos se fueron, y "pecaron".

Vistas como un conjunto de historias relacionadas y conectadas, prosigue el mito de Pariacaca. Se dice que esta deidad estaba naciendo. Así pues, "Entonces, \{una vez\}, el día señalado, Huatyacuri fue a Condorcoto" (Taylor 1987: 101), a encontrarse con su padre. Allí nació Pariacaca, la nueva deidad que controlaría la Sierra Central. En efecto, "Allí estaba Pariacaca [en forma de] cinco huevos. Cerca de él, el viento empezó a soplar" (Taylor 1987: 101). A la vez, el hombre que había estado casado con la hija del "falso sabio" desafió a Huatyacuri, quien aceptó los desafíos. Pariacaca, su padre, le dijo que aceptara los desafíos y que lo fuera a ver antes de cada uno de ellos. Analicemos este trazo del mito. El primer desafío consistió en bailar y en beber chicha de maíz $\rightarrow$ Venció Huatyacuri. El segundo desafío consistió en ataviarse con las más finas plumas de casa y de cancho $\rightarrow$ Venció por segunda vez. A partir del tercer desafío los oponentes se impusieron traer un puma $\rightarrow$ Venció por tercera. En el cuarto desafío los desafiantes compitieron en construir una casa $\rightarrow$ Venció por cuarta vez. Y en el quinto desafío los adversarios tuvieron que techar la casa construida $\rightarrow$ En este desafío venció nuevamente Huatyacuri. Como es evidente, el hijo de Pariacaca, dotado de poderes, pudo imponerse en cada uno de los desafíos ante el otro personaje. Lo que en términos concretos podría significar que el hijo de Pariacaca consiguió cumplir con sus planes del que arribaba a la región para regir a los seres humanos. Finalmente, es Huatyacuri quien planteó un último desafío. En el manuscrito quechua se dice que: "Después de haberle ganado en todo, el pobre, siguiendo el consejo de su padre, dijo [a su rival]: 'Hermano, tantas veces ya he aceptado tus desafíos; ahora te toca a ti aceptar el desafío que voy a hacerte yo. [El hombre rico] aceptó"” (Taylor 1987: 111). El desafío era bailar vestidos con una cusma azul y una huara blanca. Pero la historia no tiene un fin a la manera española medieval, como podría esperarse. Tanto el hombre rico como la mujer huyeron al cerro, donde Huatyacuri para "castigarlos" los convirtió en piedra. Estas piedras fueron transformadas en huacas donde la gente acudía a ofrendar hojas de coca en las épocas rituales. El hombre rico convertido en venado da origen a otra historia, que aquí no viene al caso. No nos desconcierta este desenlace, ya que ahora sabemos que la mentalidad andina tiene otra forma de entender las relaciones humanas y sobrenaturales: el triunfo siempre es de la armonía humana con la naturaleza (no con el poder, como ocurre con la mentalidad cristiana).

A partir de aquí el mito se reanuda con otras vicisitudes y simbolismos, con otros acontecimientos. Se retoma la cuestión del origen de la deidad Pariacaca. Así pues, se manifiesta la deidad junto con sus hijos: "Cuando Huatyacuri hubo terminado todas estas hazañas, Pariacaca [y sus hermanos] salieron de los cinco huevos [en forma de] cinco halcones" (Taylor 1987: 115). Aparece la imagen de otro animal totémico: el halcón (huamán), ave sagrada por su belleza estética y sus cualidades cazadoras. En este caso particular se presenta la idea de que a partir de los cinco huevos aludidos nacen cinco halcones. Estos hijos de Pariacaca se convirtieron finalmente en hombres. Estos hombres semidivinos van en adelante a seguir los designios de su padre, respecto de la manera en que los seres humanos se habían comportado en relación a él.

Entonces, cuando se enteraron de cómo se había comportado la gente de aquella época y de cómo ese hombre llamado (Tamtañamca) fingiendo ser dios, se había hecho adorar, se enojaron mucho a causa de esos pecados y, convirtiéndose en lluvia, los arrastraron con todas sus casas y sus llamas hasta el mar sin dejar que uno solo se salvase (Taylor 1987: 117).

La falta que cometió este personaje le hizo granjearse el rencor de la deidad dominante que decide castigarle no solamente a él sino que también a todo el pueblo que lo secundó en sus falsedades. El castigo definitivo será su aniquilación por las fuerzas de la naturaleza que controlaba Pariacaca. $\mathrm{La}$ singularidad y coherencia del texto mítico-histórico aparece cuando el análisis nos permite entender su 
significado profundo y las relaciones recíprocas de sus componentes poéticos y simbólicos. Todo esto demuestra que el verdadero valor de este texto misional es precisamente el hecho de que todos los personajes están "puestos en escena" cumpliendo roles y funciones que el viejo sistema de ideas logró desarrollar durante siglos, como José María Arguedas ya lo reconociera. Es interesante que el escritor del Manuscrito Quechua se detuviese en la mención de una especie peculiar: el pullao, árbol nativo en el que moraban monos, caquis y pájaros, que también fue arrastrado hasta el mar. Los árboles tienen valor como figuras naturales que representan mallquis o antepasados momificados. Creemos que cada elemento tiene su sentido de acuerdo con el valor que en el mundo andino se le concede a cada creación de la naturaleza.

En fin, "al cumplir [su castigo], Pariacaca subió [al cerro] que llamamos hoy Pariacaca" (Taylor 1987: 119). Allí se entronizó la deidad recién nacida. La forma de pensar antigua construyó el aspecto material de la deidad en hitos concretos de la geografía y la ecología, formando deidades sagradas. En este caso es el nevado sempiterno que aún hoy lleva su nombre, el que protegerá a las comunidades étnicas de sus alrededores, así como el ари Ausangate y el apu Salkantay protegían al Qosqo Inca. Las aguas de los deshielos de estos apus eran la fuente esencial de la productividad agrícola y ganadera: por ello los hombres antiguos realizaban la Qhapaq Qocha. El mito que estudiamos indica que al cabo de estos hechos la deidad Pariacaca pudo empoderarse de su función sagrada y logró ser venerado por los hombres de la región. Estructuralmente indica que hubo una transformación de la ideología dominante en la región Yunga. Pero la historia no termina aquí, por supuesto. La deidad comenzó su período de dominación, lo que equivale a pensar en la creación dinámica de nuevos ritos que se asociaron a este mito triunfante. Argumentalmente, la entronización de la deidad daba inicio a un nuevo ciclo de periplos de héroes culturales, una vez que los Yungas de Anchicocha quedaron bajo su campo de influencia.

El relato continúa su desarrollo refiriendo lo que Pariacaca hizo en Huarochirí: "/Se dice que/ Pariacaca, convertido en hombre, ya grande, se puso a buscar a su enemigo. El nombre de este era Huallallo Carhuincho. Solía comerse a los hombres y beberse [¿su sangre?]" (Taylor 1987: 121). Comentamos al inicio de este segmento temático la lucha entre ambas deidades. A partir de aquí la narración nos relata lo que ocurrió en este dramático encuentro. Hubo en efecto una lucha entre Pariacaca y Huallallo. En el caso del adversario de la deidad estudiada parece que se tratase de una deidad que exigía sacrificios humanos (vemos aquí a la Qhapaq Qocha "demonizada" por la moral de Ávila y Thomas), lo que por supuesto importunaba notoriamente a Pariacaca, que no los aceptaba (¿hay en esta idea una consideración moral cristiana que suaviza el relato oral recogido? Los sacrificios humanos fueron uno de los ejes de la impugnación cristiana sobre las religiones del Nuevo Mundo. Pero claramente los sacrificios humanos de México marcan el punto de vista de los evangelizadores de los Andes). Este motivo y probablemente otros más no expresados, inician la lucha entre las deidades. Ahora bien, como ahora sabemos más detalladamente, el Manuscrito Quechua por Yndio Runa Niscap fue un conjunto sistemático de informaciones filtradas por la mente cristianizada de Thomas y por su manejo adecuado de la escritura que logró manipular ideológicamente las informaciones recogidas. A la vez, es también la lengua castellana la que al traducir las informaciones que los interrogados expresan en lengua quechua desvirtúa e invierte el problema de la traducción creando una modalidad misional que se apropia del espacio religioso de la fe. Y aun el desprecio religioso hacia lo "pagano" aporta otro tanto de desfiguración de la cosmovisión andina. Aunque este resquemor moral no incluía el material metálico o natural de objetos rituales valiosos (conopas, queros, chaquira) que les proporcionaba riqueza material a los "extirpadores". Por tanto, podemos deducir que el relato contiene ideas cristianas que contaminaron semánticamente lo que los informantes indígenas originalmente declararon, creando traducciones manipuladas e interesadas. Esto es importante de tener claro para una correcta compulsa exegética de este valioso documento. Continuemos con los prodigios de Pariacaca: "Cuando ya era un hombre grande, se encaminó hacia Pariacaca de arriba donde se situaba la morada de Huallallo Carhuincho. En la quebrada más debajo de Huarochirí había una comunidad de yuncas llamada Huayquihusa" (Taylor 1987: 121). La deidad Pariacaca se desplazó hacia las alturas de las montañas para enfrentarse a Huallallo. Pero se produjo un giro que abre una nueva línea dramática: se menciona la existencia de una comunidad de Yungas (Huayquihusa) que habita el pueblo de Huarochirí. 
A partir de aquí el lenguaje del texto desarrolla nuevas historias que se van enlazando con otras creando la compleja red de tradiciones, probablemente como conjuntos de relatos interrelacionados que explican diversas situaciones acaecidas en aquellos tiempos. Nuevamente aparece el comportamiento de la deidad-como hemos visto en el comportamiento de Cuniraya y Huatyacuri- que se disfraza para engañar a las personas del pueblo. Así, "En esa época, los miembros de esa comunidad celebraban una fiesta importante con una gran borrachera. Mientras bebían, llegó Pariacaca. Se sentó a un lado como suelen hacer los pobres. Ninguno de los Huayquihusa le sirvió de beber" (Taylor 1987: 123). Como hemos advertido, se repite una actitud que nos parece una auténtica reminiscencia de las cualidades de las deidades en la manera de pensar la díada "lo natural/lo sobrenatural". Pariacaca engaña y burla a los participantes de la fiesta. Entre ellos el ser divino actúa como un hombre pobre. Al ser percibido como un menesteroso no es considerado ni tomado en cuenta por los celebrantes. No se le prodiga atención, o siquiera bebida o alimento. Esto es así, según deducimos, ya que las personas que lo subvaloran debido a su aspecto, lo perciben como un ser despreciable. Lo que está en juego en el tono del lenguaje simbólico es la soberbia de los poderosos frente a otros individuos de condición humilde (recordemos que Cavillaca rechaza a Cuniraya por su aspecto miserable). Quizás la deidad estaría reconociendo el verdadero corazón $(\rightarrow$ camaq) de estos sujetos. El hecho es que estas personas no sintieron piedad por el recién llegado. La deidad resiente la maldad y el egoísmo de estos individuos. Podemos ver en esto la superioridad de espíritu de la deidad ante los hombres. Pero una mujer se apiada de este "pobre hombre" y le sirve chicha. En agradecimiento por su gesto de bondad la deidad le advierte que huya del lugar, ya que haría caer sobre el pueblo un castigo. Le obliga a guardar silencio a cambio de salvar su vida. La mujer hace caso de la advertencia y se va del pueblo con su familia, mientras los otros siguieron bebiendo.

Entonces, "Pariacaca subió al cerro que está arriba de Huarochirî" (Taylor 1987: 125). En aquellas alturas existen dos cerros a los cuales ascendió nuestra deidad: uno se llama Mataocoto y el otro se llama Puypuhuana. Desde este lugar desplegó la potencia de su castigo convocando a las fuerzas naturales que controlaba, las lluvias torrenciales:

\begin{abstract}
(...) En ese cerro [¿de Mataocoto?], Pariacaca [se transformó en] tempestad de lluvia. Y bajo la forma de granizo amarillo y rojo, arrastró a toda aquella gente hasta el mar sin perdonar a nadie. Entonces, esta gran cantidad de agua, hecha torrentes, cavó las quebradas de las alturas de Huarochirí (Taylor 1987: 125).
\end{abstract}

Las gentes del pueblo fueron arrastrados hasta el mar, nadie sobrevivió. Entonces Pariacaca se fue a otra comunidad. Aquí aparece otro pliegue del mito. El personaje divino llegó a la comunidad de los cupara, otra etnia Yunga. Esta comunidad tenía un grave problema con el agua: la única acequia que poseían no lograba irrigar sus chacras. Esto ocurrió, según los declarantes de la interrogación de Ávila y sus asesores, en el pueblo de San Lorenzo cercano al cerro Sunacaca. Allí había una laguna grande. Y desde allí sacaban el agua para las chacras. Señala el texto:

Había entonces en esta comunidad una mujer muy hermosa de nombre Chuquisuso. Como el agua era muy poca y su maíz se estaba secando, esta mujer regaba su chacra llorando. La mujer lloraba al ver disminuir cada vez más el agua. Cuando Pariacaca vio esto, cubrió la bocatoma de la pequeña laguna con su manta (Taylor (1987: 127)).

La mujer y Pariacaca acordaron acostarse siempre que solucionase el asunto del agua. Pariacaca cumplió su palabra y la mujer muy contenta regó sus chacras. La deidad al terminar su cometido insistió en dormir con la mujer. Pero ella se negaba y lo dejaba en suspenso. Pariacaca prometió a la mujer producir más agua en la acequia que había agrandado. La acequia llegó hasta las comunidades de los cupara de abajo.

El espacio de nuestro análisis lamentablemente no nos permite continuar con el estudio de la saga completa. Cerrando este ensayo, digamos que fueron los "pumas, zorros, serpientes y todas las variedades de pájaros (quienes) arreglaron la acequia" (Taylor 1987: 131), los que convocados por la deidad trabajaron arduamente para crear el canal que permitiría asegurar el suministro de las aguas necesarias para los cultivos. En este tramo de la narración los animales debatieron quién iba a trazar el curso de la acequia. Todos querían asumir 
la tarea. El zorro se quedó con la tarea. Pero no pudo realizar el mandato. La serpiente tuvo que realizarlo.

Por su parte, la deidad Pariacaca insistió con la mujer:

Ella le contestó: "vamos a la peña allí arriba; allí estaremos juntos". Esta peña se llama hoy Yanacaca. /Se dice/ que allí se unieron. "Vayamos los dos a algún lado", dijo la mujer. Y Pariacaca: " Vamos!" y se la llevó a la bocatoma de la acequia de Cocochalla. Cuando llegaron, la mujer llamada Chuquisuso le dijo: "Aquí en mi acequia me voy a quedar" y se transformó en piedra. Pariacaca la dejó allí y siguió subiendo (Taylor 1987: 135).

Finalmente, Pariacaca y Chuquisuso se unieron. Este hecho deja abierta la pregunta del sentido de estas uniones furtivas. Interpretamos que el ideal de la complementariedad sexual se realiza resolviendo los problemas humanos más relevantes, $\mathrm{o}$, dicho de otro modo, es la complementariedad la que permite al hombre y la mujer coexistir armoniosamente en la tierra. Entonces Chuquisuso se transformó en piedra, en huaca, y cumplió con su función de prodigar las aguas para el cultivo. Los interrogados y los investigadores "antiidolátricos" señalaron que en efecto: "La mujer llamada Chuquisuso aún se encuentra, petrificada, en la bocatoma de esta acequia de Cocochalla" (Taylor 1987: 135). Así la huaca aseguró el flujo de las aguas: se eternizó como la deidad que prodigaría este recurso a los seres humanos de esta comunidad. Un último asunto es necesario señalar para terminar esta idea: la deidad Cuniraya también estuvo allí convertido en piedra, cerca de otra acequia llamada Huincompa. Esta deidad también se vinculaba a la abundancia de aguas, o tal vez, como ha señalado César Itier (Op. cit.), sea el origen de todas las aguas. Hay entonces una notable adscripción de varias deidades en torno a este imprescindible recurso en estas sociedades de agricultores y ganaderos. El texto lo clarifica particularmente: "Fue allí donde Cuniraya acabó" (Taylor 1987: 137).

El Manuscrito Quechua de Huarochirí nos entrega varias informaciones que adecuadamente interpretadas nos ayudan a comprender mejor los aspectos involucrados en torno al fenómeno del dominio de la escritura indígena y del modo ideológico en que consiguieron presentar el pasado en el mundo andino colonial de los siglos XVI y XVII.

\section{Conclusión}

El Runa Yndio Niscap expone interesantes problemas antropológicos, en el sentido de lo que queda eclipsado, desbordado y superado por el obturador escritural. Como bien sabemos, la evangelización de los Andes fue conducida con amplios criterios especialmente desde el Tercer Concilio Limense de 1582-83, utilizando una estrategia definitiva de convencimiento ideológico: el uso de las lenguas castellana, quechua y aymara (vgr. Doctrina Christiana [1584]) y una teología que asimilaba lo andino en aquellos puntos que resultaban afines al cristianismo. La explosión de fanatismo religioso, despertada por la campaña de contrarreforma que la Iglesia Católica llevó adelante en Europa, generó las condiciones para que algunos de sus miembros entrasen en franca colisión con los viejos sistemas de creencias de los grupos étnicos Yungas, lo que Henrique Urbano llamó "el episteme inquisitorial andino" (Urbano 1999: LXXXI), que pudo fundamentar la extirpación de idolatrías. No solo existieron intereses espirituales que inspiraban esta campaña, sino que también influyeron varios intereses económicos que estuvieron en juego en la persecución de las creencias autóctonas y probablemente también intereses políticos a nivel burocrático, agravando la situación de los "idólatras"15.

El abordaje de este tipo de materiales historiográficos, contemplados desde el punto de vista de las traducciones coloniales y republicanas, y el significado e importancia que estas traducciones implican, nos ponen en contacto con la cuestión ideológica, lingüística y cultural que está presente en forma implícita y explícita en este documento, y nos enfrenta a un dispositivo escritural que intenta captar los relatos o confesiones de los hombres cuestionados por sus creencias. Nuestros resultados investigativos nos obligan a contrastar dos formas radicalmente distintas de expresar lo comunicativo: el "sistema de signos andinos" y la historiografía colonial. El primero, un dispositivo original que incluyó en su sistema general un conjunto de métodos o técnicas comunicativas que correlacionadas crearon un lenguaje rico y comprensible para las sociedades que interactuaban en un contexto claramente multiétnico y plurilingüe, que resultó 
arruinado por la institución "antiidolátrica". El segundo, un dispositivo occidental que poseía una técnica definitiva: un registro escritural que consiguió mediante el control de las lenguas nativas más importantes estandarizar y normalizar las ideologías indígenas por medio de gramáticas, diccionarios y literatura edificante.

Conocer y comprender en detalle lo que en el texto aparece relatado como "fábulas" o "fantasías", es decir, las historias míticas antiguas, nos enseña a valorar la forma del pensamiento andino antiguo. La información llevada del quechua oral al quechua misional implicó que el sistema escriturario consiguiera interceptar las tradiciones Yungas y las filtrara utilizando la perspectiva ideológica cristiana, generando profundos problemas de traducción. Por una parte, porque no sabemos exactamente si la operación dialógica oral en lengua serrana fue apegada al ciclo interrogado-interrogador-escribano, o si, por la otra, fue debidamente llevada a la expresión escrita. Al haber sido Thomas un individuo indígena podemos hipotetizar que por este hecho conocía mucho mejor el pensamiento religioso de los Yungas. El análisis e interpretación de las historias míticas de dos importantes deidades nos ofrece un verosímil acceso a la mentalidad antigua. Respecto de Cuniraya Huiracocha, hemos visto cómo su figura panandina expresaba varias formas tradicionales de entender la funcionalidad de los roles masculino y femenino, la sexualidad y la reproducción. Las historias míticas que nos narra el Manuscrito Quechua son reveladoras porque reproducen una cosmovisión de la que se beneficiaba la etnia en tanto estos relatos representaban perspectivas filosóficas que inspiraron a los hombres, permitiendo la reflexión acerca de los fenómenos naturales y sobrenaturales haciendo comprensible la realidad. Respecto del segundo, Pariacaca, el estudio mitográfico del relato de sus avatares, peripecias y sus relaciones con otras figuras sagradas, nos explica los vínculos, conexiones y conflictos de los grupos étnicos que coexistieron en aquella época y en aquel territorio común. Desde el punto de vista de la cultura, estudiando los ritos antiguos entendemos más respecto de las necesidades comunitarias, psicológicas, espirituales y económicas de los pueblos andinos del pasado. Este análisis nos permite penetrar en su pensamiento antiguo y percibir las categorías cognitivas de las poblaciones quechuahablantes de la Sierra y Costa Central.

La conservación del Manuscrito Quechua permitió que varios aspectos del sistema religioso Yunga quedasen resguardados como testimonios de las antiguas tradiciones y creencias por medio del recorte arbitrario historiográfico. Lo que los extirpadores de idolatrías utilizaron y manipularon, censuraron y combatieron, nos parecen evidencias documentales suficientes de la riqueza de las tradiciones y creencias de los Yauyos. Y si bien es cierto que estos documentos no tuvieron la intención de salvaguardar "etnográficamente" lo que precedió a las enseñanzas de la Santa Biblia, paradójicamente los sujetos andinos que los produjeron de alguna manera intuyeron el poder de las palabras y los textos, y lo aprovecharon para dejar memoria del pensamiento antiguo y de las formas de vida de sus ancestros.

\section{Agradecimientos}

Como siempre aprecio el apoyo en la lengua inglesa del Profesor René Nicolai Riquelme.

\section{Referencias Citadas}

Acosta, Antonio

1987 "Estudio biográfico sobre Francisco de Ávila", pp. 551616. En: Ritos y tradiciones de Huarochirí. Manuscrito Quechua de comienzos del siglo XVII [¿1609?] Versión paleográfica, interpretación fonológica y traducción del castellano por Gerald Taylor. Lima. IEP/IFEA.

Arguedas, José María. ed.

2007 Dioses y hombres de Huarochirí. Narración quechua recogida por Francisco de Ávila [¿1598?]. Lima. Universidad Antonio Ruiz de Montoya, Jesuitas.

ed. [1967] 2012 Dioses y hombres de Huarochirí. Narración quechua recogida por Francisco de Ávila [i1598?]. Edición bilingüe. Traducción castellana de José María Arguedas. Estudio biobibliográfico de Pierre Duviols. Lima. IEP.
Armas Medina, Fernando de 1953 La cristianización del Perú, 1532-1600. Sevilla. Escuela de Estudios Hispanoamericanos.

Arriaga, Joseph de

[1621] 1999 La extirpación de la idolatría en el Perú. Estudio preliminar y notas de Henrique Urbano. Cuzco. CBC.

Bauer, Brian S.

2011 Estudios arqueológicos sobre los incas. Cusco. CBC.

Cook, Noble David

[1998] 2005 La conquista biológica: las enfermedades en el Nuevo Mundo. Traducción de María Asunción Gómez. Madrid. Siglo XXI Editores.

[1981] 2010 La catástrofe demográfica andina. Perú, 15201620. Lima. Fondo Editorial PUCP. 
Demarest, Arthur A.

1982 Viracocha, the nature and antiquity of the Andean High God. Monographs of the Peabody Museum, $\mathrm{N}^{\circ} 6$. Cambridge MA. Peabody Museum Press.

Doctrina Christiana y Catecismo para la instrucción de los indios... [1584] 1985 Imprenta de Antonio Ricardo. Edición facsimilar. Lima. PetroPerú.

Duviols, Pierre

1977 La destrucción de las religiones andinas. Conquista y colonia. México. UNAM.

2003 Procesos y visitas de idolatrías. Cajatambo, siglo XVII. Lima. Fondo Editorial PUCP/IFEA.

Estenssoro Fuchs, Juan Carlos

2003 Del paganismo a la santidad. La incorporación de los indios del Perú al catolicismo. 1532-1750. Lima. PUCP/ IFEA.

García Cabrera, Juan Carlos

1994 Ofensas a Dios, pleitos e injurias. Causas de idolatrías y hechicerías. Cajatambo, siglos XVII-XIX. Cusco. CERACBC.

González Holguín, Diego

[1609] 1989 Vocabulario de la lengua general de todo el Perú llamada lengua qquichua o del Inca. Lima. Editorial de la Universidad Nacional Mayor de San Marcos.

Goody, Jack

1985 La domesticación del pensamiento salvaje. Madrid. Akal.

Griffiths, Nicholas

1998 La cruz y la serpiente. La represión y el resurgimiento religioso en el Perú colonial. Lima. PUCP.

Hill Boone, Elizabeth y Walter Mignolo comps. 1994 Writing without words. Alternative literacies in Mesoamerica \& the Andes. Durham. Duke University Press. Itier, César.

2013 Viracocha o el océano. Naturaleza y funciones de una divinidad inca. Lima. IFEA/IEP.

Kirk, G.S.

[1970] 2006 El mito. Su significado y funciones en la Antigüedad y otras culturas. Barcelona. Paidós.

Levi-Strauss, Claude

[1962] 1997 El pensamiento salvaje. México. FCE.

[1968] 2013 Lo crudo y lo cocido. Mitológicas I. México. FCE.

Mannheim, Bruce

2002 “Gramática colonial”, pp. 209-220. En: Jean Jacques Decoster ed. Incas e indios cristianos. Élites indígenas e identidades cristianas en los Andes coloniales. Cuzco. IFEA/CBC/Asociación Kuraka.
Millones, Luis y Renata Mayer

2012 La fauna sagrada de Huarochirí. Lima. IEP/IFEA.

Ong, Walter J.

[1987] 2004 Oralidad y escritura. Tecnologías de las palabras. México. FCE.

Pease, Franklin

1973 El dios creador andino. Lima. Mosca Azul.

Taylor, Gerald ed.

[¿1609?] 1987b Ritos y Tradiciones de Huarochirí. Manuscrito Quechua de comienzos del siglo XVII. Lima. IEP/IFEA.

ed. [¿1609?] 1999 Ritos y Tradiciones de Huarochirí. Segunda edición revisada. Lima. IFEA/ BCRP/ UPRP.

Ramos, Gabriela comp.

1994 La venida del reino: religión, evangelización y cultura en América, siglos XVI y XX. Cusco. Centro de Estudios Regionales Andinos Bartolomé de Las Casas.

Rostworowski, María

2007 Obras completas. Ensayos de historia andina II. Vol. V. Lima. IEP.

Salomon, Frank, Jane Feltham y Sue Grosboll

2009 La revisita de Sisicaya, 1588. Huarochirí, veinte años antes de Dioses y Hombres. Lima. Fondo Editorial PUCP.

Spalding, Karen

2008 "Consultando a los ancestros", pp. 273-292. En: Marco Curatola Petrocchi y Mariusz S. Ziólkowski eds. Adivinación y oráculos en el mundo andino antiguo. Lima. PUCP.

Szemiñski, Jan

1997 Wira Quchan y sus obras. Teología andina y lenguaje, 1550-1662. Lima. IEP/BCRP.

Urbano, Henrique

1981 Wiracocha y Ayar. Héroes y funciones en las sociedades andinas. Cusco. Centro de Estudios Regionales Andinos Bartolomé de Las Casas.

1999 "Estudio preliminar y notas". En: Joseph Pablo de Arriaga. [1621] 1999. La Extirpación de la Idolatría en el Pirú. Estudio preliminar y notas de Henrique Urbano. Cusco. CBC.

Vargas Ugarte, Rubén S.J.

1953-62 Historia de la Iglesia en el Perú (1511-1568). 5 vols. Lima-Burgos. Imprenta Santa María.

Villanueva Urteaga, Horacio ed.

1982 Cuzco 1689. Documentos: los informes de los párrocos al Obispo Mollinedo. Economía y sociedad en el sur andino. Cusco. CBC.

Zuidema, Reiner Tom.

2011 El calendario incaico. Ensayos de cultura andina. Lima. Fondo Editorial del Congreso del Perú/PUCP.

\section{Notas}

1 Armas Medina (1953); Vargas Ugarte (1953-62) y (1954); Duviols (1977); Ramos comp. (1994); Urbano (1999); Estenssoro (2003); Salomon, Feltham y Grosboll (2009).

2 El jesuita Joseph de Arriaga ([1621] 1999: 20-21, 26-30, 32-36, etc.), quien dirigió por aquellos primeros años del siglo XVII Colegios de Educación tanto en Lima como en Arequipa, además de ser el organizador de la tristemente célebre Casa (o Cárcel) de la Santa Cruz, expresa horrorizado las múltiples tradiciones religiosas de estas etnias, todos distintos y absolutamente ajenos a la "santidad" de su religión.

3 Acosta (1987: 562); Arguedas (2007: 9-15); Duviols (2007: 217); Millones y Tomoeda (2007: XIII-XXXII); Duviols (2007: 215-274).

$4 \quad$ Véase Griffiths (1998); Mannheim (2002); Spalding (2008); Millones y Mayer (2012).

5 Según Taylor (1987: 15): "Se conserva entre un conjunto de otros documentos relacionados a la religión y a la 
organización de la sociedad precolombina del Perú en un volumen que lleva el título de uno de estos documentos: Molina Fabula y Ritos de los Ynga, Ms 3169 de la Biblioteca Nacional de Madrid [... . Se puede suponer que el conjunto de manuscritos perteneció originariamente al investigador de idolatrías, el doctor Francisco de Ávila [...]".

$6 \quad$ Vgr. Villanueva Urteaga ed. (1982); García Cabrera ed. (1994); Duviols ed. (2003).

7 Véase Goody (1985: Caps. I-II-III) y (1990); Lévi-Strauss (1997); Ong (2004); Hill Boone y Mignolo comps. (1994).

8 En este hipotético sistema sígnico confluyeron varios soportes complementarios de la oralidad primaria. Su estudio puede permitir una nueva manera de enfocar el problema de la unilateralidad de las versiones historiográficas escritas por los hispánicos. La expresión visual y oral pueden considerarse una "Cultura Oficial": un sistema, un dispositivo, un método. Esta cultura de la comunicación en los Andes prehispánicos debemos deducirla no necesariamente accesible a toda la población; el mundo de la educación en el manejo especialista de estos códigos estuvo también estratificado. Al parecer solo las élites controlaron la totalidad compleja de estos sistemas que se enseñaron en el Qosqo antiguo probablemente en el Yachay Wasi o en el Aclla Wasi, aun cuando sus signos eran presumiblemente comunes a todo el mundo. Las sociedades Chimú y Qolla en los siglos XV y XVI también tuvieron complejos sistemas comunicativos, legados por sociedades más antiguas. En el mundo andino prehispánico no todos los individuos conocían y comprendían este sistema, no obstante, sí conseguían ser compartidos por todos gracias a los dialectos y a tradiciones diglósicas, en el contexto de la realización de las ceremonias y rituales, según las especificidades étnicas regionales. Preparamos en este momento (2015) una primera propuesta que fundamenta nuestra hipótesis del "sistema de signos andinos".

$9 \quad$ Véase nuestra tesis doctoral (2016).

$10 \quad V g r$. Cieza de León [1550]; Betanzos [1551]; Ondegardo [1571]; Sarmiento de Gamboa [1572].

11 En la práctica, el sistema de escritura introducida en los Andes para efectos del desarrollo de los patrones culturales propios de los europeos que requerían esta tecnología para sus múltiples labores administrativas, económicas, jurídicas, teológicas y literarias, fue aprovechada por "autores andinos" que consiguieron apropiarse igualmente de las palabras y los signos antiguos (mito-historia/arte precolombino). Este hecho configura el fenómeno de emergencia de discursos histórico-literarios indígenas en el contexto colonial, expresándose de dos formas: uno) tuvo efectos disolventes en muchos aspectos de la memoria indígena sobreviviente, y dos) paradojalmente el recurso de la palabra escrita en manos andinas recobró inesperadamente varios aspectos de la memoria andina antigua.

12 Para Diego González Holguín "Viracocha" significa: "Era epicteto, del sol honrroso nombre del Dios que adorauan los indios y de ay ygualandolos con su Dios llamauan a los españoles viracocha" ([1609] 1989: 353).

13 Pease (1973); Urbano (1981); Demarest (1982); Szemiñski (1997); Itier (2013).

14 Zuidema (2011) plantea la existencia de calendarios lunares y solares para el Cuzco incaico. Su interesante trabajo debe estudiarse con mayor detenimiento para verificar hasta qué punto su hipótesis puede ser aplicable a otras áreas de los Andes.

15 Véase Duviols (1977: Cap. IV); Acosta (1987: 564-65). 